\title{
Synaptotagmin: A Membrane Constituent of Neuropeptide-containing Large Dense-Core Vesicles
}

\author{
Christiane Walch-Solimena, ${ }^{1}$ Kohji Takei, ${ }^{1}$ Kenneth L. Marek, ${ }^{2}$ Kurt Midyett, ${ }^{2}$ Thomas C. Südhof, $^{5}$ \\ Pietro De Camilli ${ }^{1,3}$ and Reinhard Jahnn ${ }^{1,3,4}$ \\ 1Howard Hughes Medical Institute, ${ }^{2}$ Department of Neurology, ${ }^{3}$ Department of Cell Biology, and ${ }^{4}$ Department of \\ Pharmacology, Yale University School of Medicine, New Haven, Connecticut 06510 and ${ }^{5}$ Howard Hughes Medical \\ Institute and Department of Molecular Genetics, Southwestern Medical Center, University of Texas, Dallas, Texas 75235
}

Synaptotagmin is known to be a major membrane protein of synaptic vesicles (SVs) in neurons. We have now used an immunoisolation procedure to demonstrate that synaptotagmin is also present in the membranes of peptide containing large dense-core vesicles (LDCVs) of rat hypothalamus and bovine posterior pituitary. Synaptotagmin bead-immunoisolated organelles from these tissues primarily consisted of SVs but contained occasionally larger structures reminiscent of LDCVs that were absent from vesicle populations immunoisolated with a synaptophysin antibody. Furthermore, the vesicles immunoisolated with synaptotagmin beads contained significant amounts of neuropeptide Y (NPY). In contrast, vesicles immunoisolated with synaptophysin beads did not contain detectable levels of NPY.

Sucrose density gradient fractionation of postnuclear supernatants obtained from the bovine posterior pituitary resulted in a bimodal distribution of synaptotagmin, corresponding to the positions of both SVs and neurosecretory granules. A similar distribution was found for cytochrome b561 and the $116 \mathrm{kDa}$ subunit of the vacuolar proton pump. In contrast, the SV proteins synaptophysin, SV2, and p29 were restricted to the SV-containing fractions. Immunoisolation of small and large vesicles from the sucrose gradient confirmed the differential distribution of synaptotagmin and synaptophysin in the two types of secretory vesicles in nerve endings of the posterior pituitary. We conclude that synaptotagmin is a constituent of both SVs and peptide-containing secretory vesicles in the nervous system. Since both types of organelles undergo $\mathrm{Ca}^{2+}$-dependent exocytosis, these findings support a general role of synaptotagmin as an exocytotic $\mathrm{Ca}^{2+}$ receptor.

[Key words: synaptic vesicle, synaptotagmin, synaptophysin, large dense-core vesicle, neuropeptide $Y$, immunoisolationl

Neurons store their transmitters in at least two types of secretory organelles. Nonpeptide transmitters are stored in small, translucent vesicles of uniform size (synaptic vesicles, SVs), whereas

\footnotetext{
Received Sept. 15, 1992; revised Feb. 10, 1993; accepted Mar. 30, 1993.

We thank Laurie Daniell for excellent technical assistance and Robert Mann for help with computer software.

Correspondence should be addressed to Christiane Walch-Solimena, Howard Hughes Medical Institute, Yale University School of Medicine, Boyer Center for Molecular Medicine, 295 Congress Avenue, New Haven, CT 06510.

Copyright (C) 1993 Society for Neuroscience $0270-6474 / 93 / 133895-09 \$ 05.00 / 0$
}

neuropeptides are stored in larger, more heterogeneous vesicles with an electron-dense core (large dense-core vesicles, LDCVs). Both organelles release their content via calcium-dependent exocytosis, but differ in their release mechanisms (Matteoli et al., 1988; Hökfelt, 1991; Verhage et al., $1991 \mathrm{a}, \mathrm{b})$, their site of release (Thureson-Klein and Klein, 1990), and their biogenesis. While LDCVs are formed as morphologically distinct organelles in the outer cisternae of the trans-Golgi network (TGN) (Orci et al., 1987; Tooze et al., 1987; Klein and Thureson-Klein, 1990; Tooze and Huttner, 1990; Jung and Scheller, 1991), SV membrane proteins appear to follow a separate route from the TGN to the plasma membrane that may involve cotransport of SV precursors with the constitutive pathway (Régnier-Vigouroux et al., 1991). After exocytosis, SVs undergo many rounds of local recycling in the nerve terminal (Ceccarelli et al., 1973; Heuser and Reese, 1973). The fate of the LDCV membrane after exocytosis is unclear. Since LDCVs cannot be reloaded in the cell periphery, their membrane constituents must ultimately reach the TGN to be reassembled into new LDCVs.

In recent years, investigation of the membrane composition of SVs led to the identification of more than half a dozen membrane proteins specific for these organelles. SV proteins have also been discovered in peptide-secreting endocrine cells, where they are enriched in a population of small vesicles (designated as synaptic-like microvesicles, SLMVs) that are different from secretory granules (Navone et al., 1986; Wiedenmann et al., 1988; see De Camilli and Jahn, 1990, for review). Studies utilizing these proteins have allowed major progress in our understanding of SV biogenesis and membrane traffic (De Camilli and Jahn, 1990; Südhof and Jahn, 1991; Trimble et al., 1991). In contrast, little is known about membrane constituents of LDCVs. In the brain, LDCVs are rare organelles compared to SVs and have therefore been difficult to characterize biochemically. Pure LDCV preparations are available only from specialized regions of the nervous system where LDCVs abound. These regions include the posterior pituitary (Russell, 1980) and peripheral nerves of the sympathetic nervous system (Fried et al., 1978).

The distinct features of SVs and LDCVs imply differences in their protein composition or regulation. On the other hand, since both LDCVs and SVS are secretory organelles within the same cell undergoing regulated exocytosis, conserved membrane proteins (or their isoforms) are likely to be involved in shared functions such as $\mathrm{Ca}^{2+}$ binding, targeting, or membrane fusion. It remains unsolved to what extent $\mathrm{SV}$ proteins are present on 
the membrane of LDCVs or secretory granules. Subcellular fractionation experiments and immunogold labeling have demonstrated that the SV proteins synapsin I, synaptophysin, and p29 are specifically localized in the membranes of SVs in the brain and SLMVs of various endocrine cells (Navone et al., 1984, 1986; Wiedenmann and Franke, 1985; Wiedenmann et al., 1988; Baumert et al., 1990; Reetz et al., 1991). Using subcellular fractionation or immunoprecipitation, other authors have found varying amounts of synaptophysin in fractions enriched in secretory granules or LDCVs from sympathetic neurons or the myenteric plexus (Lowe et al., 1988; Agoston and Whittaker, 1989; Schwarzenbrunner et al., 1990; Schmidle et al., 1991). While most authors agree that in endocrine cells the majority of synaptophysin is localized on SLMVs, it remains controversial whether synaptophysin is also a component of the secretory granule membranes (Lowe et al., 1988; Obendorf et al., 1988; Fournier et al., 1989).

The subcellular localization of the SV protein synaptotagmin (= p65; Matthew et al., 1981; Perin et al., 1990) has been investigated by several groups. Recent studies have shown that synaptotagmin binds $\mathrm{Ca}^{2+}$ ions with high affinity in a phospholipid-dependent manner, suggesting a function as a $\mathrm{Ca}^{2+}$ receptor in exocytosis (Brose et al., 1992). In addition, synaptotagmin interacts with two recently identified proteins of the presynaptic plasma membrane, neurexin I (Petrenko et al., 1991; Ushkaryov et al., 1992) and epimorphin/syntaxin [Bennett et al., 1992; see also Hirai et al., 1992 (epimorphin), and Inoue et al., 1992 (HPC-1)], indicating direct involvement in docking and/or fusion of secretory vesicles with the plasmalemma. Since exocytosis of both LDCVs and SVs is regulated by $\mathrm{Ca}^{2+}$ (although the mechanisms may be different), it is of particular importance to clarify whether synaptotagmin is present in LDCV membranes. Indeed, there is evidence for the presence of synaptotagmin in the membrane of chromaffin granules and in LDCVs of the posterior pituitary and sympathetic neurons (Fournier and Trifaro, 1988; Trifaro et al., 1989; Perin et al., 1991a; Schmidle et al., 1991).

In the present study, we have used an immunobead isolation procedure that has been successfully applied to obtain SV fractions of high purity (Burger et al., 1989) to investigate whether synaptotagmin is present in the membranes of LDCVs in the CNS. In addition, we have reexamined the distribution of synaptotagmin in bovine posterior pituitary because we were previously unable to detect synaptotagmin in fractions enriched in neurosecretory granules (Navone et al., 1989). Our results, obtained by a combination of electron microscopy, content analysis, and immunoblotting for a large array of vesicle membrane proteins, demonstrate that synaptotagmin, in addition to the vacuolar proton pump, is a constituent of both SVs and LDCVs while synaptophysin, p29, and SV2 are largely confined to SVs and related microvesicles and cytochrome b561 appears to be confined to LDCVs.

\section{Materials and Methods}

Materials. Rabbit anti-mouse IgG was purchased from Cappel (Durham, NC). ${ }^{125}$ I-labeled protein A was purchased from Du Pont (Wilmington, DE). All other reagents were of analytical grade and were from standard commercial sources.

Antibodies. Monoclonal antibodics against synaptophysin [clone 7.2 (C 7.2); Jahn et al., 1985], synaptotagmin [clone 41.1 (Cl 41.1); Brose et al., 1992] and polyclonal antibodies against p29 (rabbit serum, affinity purified according to Baumert et al., 1990), the $116 \mathrm{kDa}$ subunit of the vacuolar proton pump (rabbit serum; Perin et al., 1991b), and cyto- chrome b561 (rabbit serum; Perin et al., 1988) were previously described. Monoclonal antibodies against SV2 (Buckley and Kelly, 1985) were kindly provided by Dr. K. Buckley (Department of Neurobiology, Harvard Medical School, Boston, MA). Monoclonal antibodies directed against chromogranin A were obtained from Boehringer (Mannheim, Germany). Polyclonal antibodies against neuropeptide Y (NPY) (Marek and Mains, 1989) were kindly provided by Dr. R. E. Mains (Department of Neuroscience, Johns Hopkins University School of Medicine, Baltimore, MD). Rabbit sera against secretogranin II were a kind gift from Drs. P. Rosa and A. Zanini (CNR Center of Cytopharmacology, Department of Pharmacology, University of Milan, Milan, Italy). Polyclonal antibodies against neurophysin-oxytocin were a kind gift of Dr. M. Treiman (Institute of Medical Physiology C, Panum Institute, University of Copenhagen, Copenhagen, Denmark).

Subcellular fractionation of bovine posterior pituitary. Fractionation of neurosecretosomes from bovine posterior pituitary was performed as described (Navone et al., 1989) with slight modifications. The homogenization medium consisted of $0.32 \mathrm{~m}$ sucrose, 4 mм HEPES, $\mathrm{pH}$ $7.4,2 \mu \mathrm{g} / \mathrm{ml}$ pepstatin (ICN), $0.1 \mathrm{~mm}$ phenylmethylsulfonyl fluoride (Pierce). For sucrose density gradient centrifugation, a continuous gradient from 2.0 to $0.4 \mathrm{M}$ sucrose was used instead of a step gradient.

Immunobead isolation of organelles. Monoclonal antibodies C 7.2 or Cl 41.1, respectively, were covalently coupled to the reactive surface of Eupergit C1Z methacrylate microbeads ( $1 \mu \mathrm{m}$ mean diameter; Roehm Pharma, Darmstadt, Germany) as described (Burger et al., 1989). Antibody-containing Eupergit $\mathrm{ClZ}$ immunobeads are referred to as synaptophysin or synaptotagmin beads, respectively. Immunoisolation of organelles was carried out at $4-6^{\circ} \mathrm{C}$. Rat hypothalamus was homogenized in $0.32 \mathrm{~m}$ sucrose, $5 \mathrm{~mm}$ HEPES, $\mathrm{pH} 7.4$, using a glass-Teflon homogenizer (10 strokes, $2000-2500 \mathrm{rpm}$ ). For biochemical experiments, the resulting homogenate was centrifuged for $20 \mathrm{~min}$ at $10,000 \times \mathrm{g}$. This relatively high precentrifugation was chosen in order to avoid cosedimentation of unspecific aggregates that otherwise would be generated during the immunobead incubation (not shown). Supernatants containing approximately $5 \mathrm{mg} / \mathrm{ml}$ protein were incubated with synaptophysin beads or synaptotagmin beads $(7 \mu \mathrm{l}$ beads $/ \mathrm{ml}$ supernatant $)$, respectively, for $30 \mathrm{~min}$ under rotation. The beads were sedimented for $1 \mathrm{~min}$ at $8500 \times g$ and washed three times in homogenization buffer. For the immunoisolation of organelles of the posterior pituitary following sucrose gradient centrifugation, fractions containing microvesicles or neurosecretory granules were pooled and incubated with $\mathrm{C} 7.2$ beads and $\mathrm{Cl} 41.1$ beads, respectively, followed by washing steps as above.

Electron microscopy. For electron microscopy of bead-bound organelles, immunobeads were added directly to homogenates of rat hypothalamus. After incubation for $30 \mathrm{~min}$ under rotation, the beads were gently settled by centrifugation for $10 \mathrm{~min}$ at $350 \times \mathrm{g}$. The pellets were directly fixed for electron microscopy in isotonic fixative $(0.25 \mathrm{M}$ sucrose, $3 \%$ formaldehyde, $2.5 \%$ glutaraldehyde in $5 \mathrm{~mm}$ phosphate buffer). Further processing of the beads for electron microscopy was performed as described previously (Cameron et al., 1991).

Other methods. The neuropeptide $\mathrm{Y}$ content of immunobead-isolated material was determined using the radioimmunoassay according to Marek and Mains (1989). SDS-PAGE was performed on $10 \%$ gels according to Laemmli (1970) using the Bio-Rad minigel system. Silver staining of proteins was performed with a commercially available kit (Sigma, St. Louis, MO). Immunoblotting was carried out according to Towbin et al. (1979) with radioiodinated protein A as the detection system (Jahn et al., 1985), using a secondary antibody conjugated to alkaline phosphatase that was visualized with a tetrazolium-based staining reaction (Harlow and I ane, 1988) or using a secondary antibody conjugated to horseradish peroxidase visualized with enhanced chemiluminescence kit (ECL, Amersham). Protein was determined by the method of Bradford (1976).

\section{Results}

Immunobeads were prepared by coupling monoclonal antibodies directed against either synaptophysin or synaptotagmin I to the surface of Eupergit $\mathrm{C} 1 \mathrm{Z}$ methacrylate beads (synaptophysin beads and synaptotagmin beads). Rat hypothalamus, a region rich in LDCVs, was homogenized and subjected to low-speed centrifugation prior to immunoadsorption to remove cell debris, nuclei, and large particles. Figure 1 shows the protein profile of the two bead fractions in comparison to the starting material. 
The profile of both bead fractions is clearly different from the starting material. Most of the major SV proteins are recognizable by protein staining resulting in a protein pattern similar to that described previously for SVs isolated by conventional procedures (Huttner et al., 1983). In addition, no difference was observed between the patterns obtained with either synaptophysin or synaptotagmin beads. This demonstrates that the majority of the bound organelles are SVs or SV-derived membranes.

To investigate whether LDCVs are adsorbed together with SVs by synaptophysin or synaptotagmin beads, immunobead fractions were prepared from hypothalamus homogenate and analyzed by electron microscopy (Fig. 2). Synaptophysin beads bound a vesicle population of uniform size $(40-60 \mathrm{~nm})$ reminiscent of SVs. A few larger membrane structures of irregular shape were found (Fig. $2 A$ ). Similar results were obtained with synaptotagmin beads that bound predominantly microvesicles corresponding to those observed on synaptophysin beads. In addition, a few organelles larger than SVs and with a dense core were observed, with a morphology reminiscent of LDCV (Fig. $2 B)$. These organelles were rare compared to SVs, which is in agreement with the relative paucity of LDCVs in comparison to SVs. However, they were found consistently in every preparation examined. To control for nonspecific binding of organelles, parallel incubations were performed with beads coupled to bovine IgG (Fig. $2 C$ ). Very little unspecific binding of organelles to these beads was observed. This demonstrates the high specificity of the isolation procedure.

The electron microscopy findings demonstrated that synaptotagmin beads, but not synaptophysin beads, were capable of binding LDCVs. However, due to the scarcity of LDCV-like organelles in comparison to the far more abundant SVs, statistically valid confirmation of the morphological findings was difficult to obtain. For these reasons, we analyzed hypothalamic bead fractions for their NPY content, an example of an LDCVcontent peptide. As shown in Figure 3, synaptotagmin beads contained on average 4.8 times more NPY than the control. In contrast, the NPY content of synaptophysin bead-isolated organelles was not significantly different from the control (average of 1.5 times) and can therefore be attributed to nonspecific adsorption. To ensure that the difference in NPY content between synaptophysin and synaptotagmin beads was not due to a different binding efficiency of the beads, the recovery of synaptophysin and synaptotagmin was analyzed by immunoblotting in each experiment. As shown in Figure 4, synaptophysin and synaptotagmin beads bound approximately equal amounts of both proteins whereas binding to control beads was negligible. Together, these results demonstrate that synaptotagmin beads but not synaptophysin beads bound neuropeptide containing organelles.

The results described above have demonstrated that synaptotagmin is a constituent of at least some LDCVs within the nervous system. We have therefore extended our study to the bovine posterior pituitary. The posterior pituitary is mainly composed of nerve endings of hypothalamic neurons that are densely populated with specialized LDCVs, the neurosecretory granules. In addition, these nerve endings contain microvesicles that were previously shown to be similar to SVs (Navone et al., 1989). Neurosecretory granules and SVs can be separated by continuous sucrose gradient centrifugation. In previous studies immunogold electron microscopy and subcellular fractionation have demonstrated that synaptophysin and the synapsins are selectively associated with microvesicles (Navone et al., 1984,

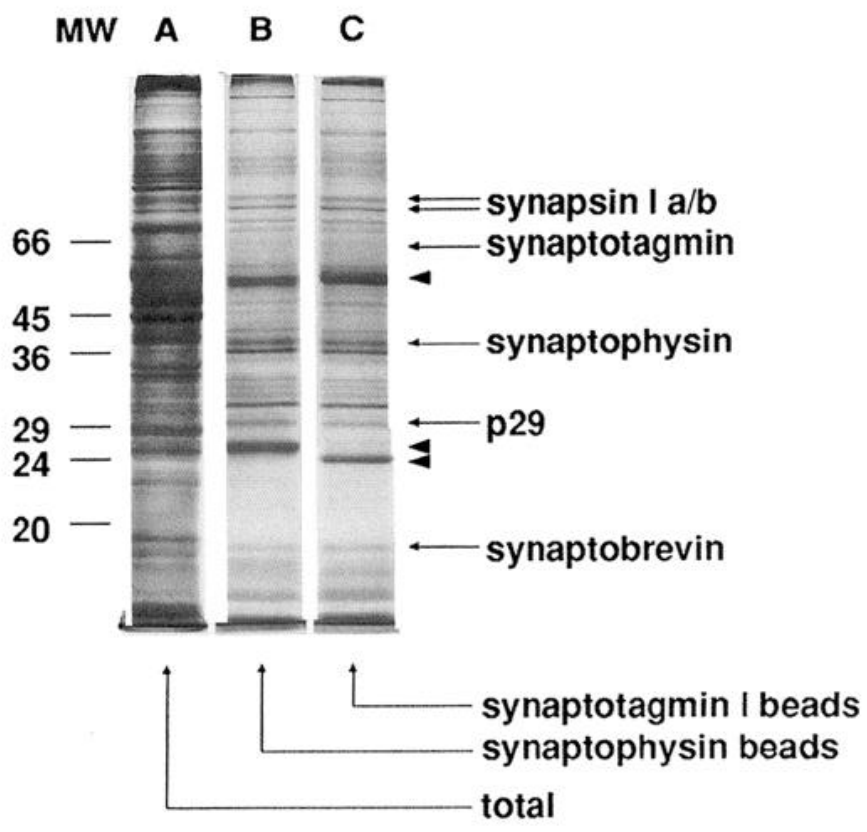

Figure 1. Protein profile of organelles immunoisolated from rat hypothalamus using synaptophysin (lane B) and synaptotagmin beads (lane $C)$. For comparison, the protein profile of the postnuclear supernatant used as starting material is shown (lane $A$ ); $15 \mu \mathrm{g}$ of protein (lane $A$ ) or $1 \mu \mathrm{l}$ of beads was separated by SDS-PAGE and visualized by silver staining. Arrowheads point to the position of $\mathrm{IgG}$ heavy and light chains of the monoclonal antibodies $\mathrm{C} 7.2$ and $\mathrm{Cl} 41.1$ that were eluted from the beads due to reduction of disulfide bonds in electrophoresis sample buffer. The position of bands corresponding to identified SV proteins is indicated.

1986, 1989). In addition, synaptotagmin (p65) as detected by a monoclonal antibody (Matthew et al., 1981) appeared to cofractionate with synaptophysin on sucrose density gradients. However, the labeling signal for synaptotagmin was relatively weak (Navone et al., 1989). We have now reexamined the distribution of synaptotagmin on sucrose density gradients using the synaptotagmin I-specific monoclonal antibody $\mathrm{Cl} 41.1$ and compared this distribution to that of an array of vesicle membrane proteins and of content proteins of neurosecretory granules.

The immunoblots (Fig. 5) show that sucrose gradient fractionation resulted in the generation of three clearly separated zones: one at the top of the gradient containing soluble proteins including secretory proteins derived from lysed granules (secretogranin II, chromograninin A, neurophysin-oxytocin), a middle region enriched in SV markers (synaptophysin, synaptotagmin, p29, and SV2; maximum at 0.9-1.0 $\mathrm{M}$ sucrose), and a bottom region enriched in neurosecretory granules as evidenced by granule content proteins (secretogranin II, chromogranin A, neurophysin-oxytocin; maximum at about $1.6 \mathrm{~m}$ sucrose). Synaptotagmin has a bimodal distribution, with peaks both at the position of the microvesicles as well as that of the neurosecretory granules. A similar distribution was found for the membrane protein cytochrome b561. Cytochrome b561 was previously shown to be a constituent of neurosecretory granules, where it transports electrons required for some of the peptide processing enzymes into the granules (Duong et al., 1984). In addition, the $116 \mathrm{kDa}$ subunit of the vacuolar proton pump cofractionated with synaptotagmin and cytochrome b561 as well as with the other SV membrane proteins. This supports previous reports that a proton-translocating ATPase is present in neurosecretory 

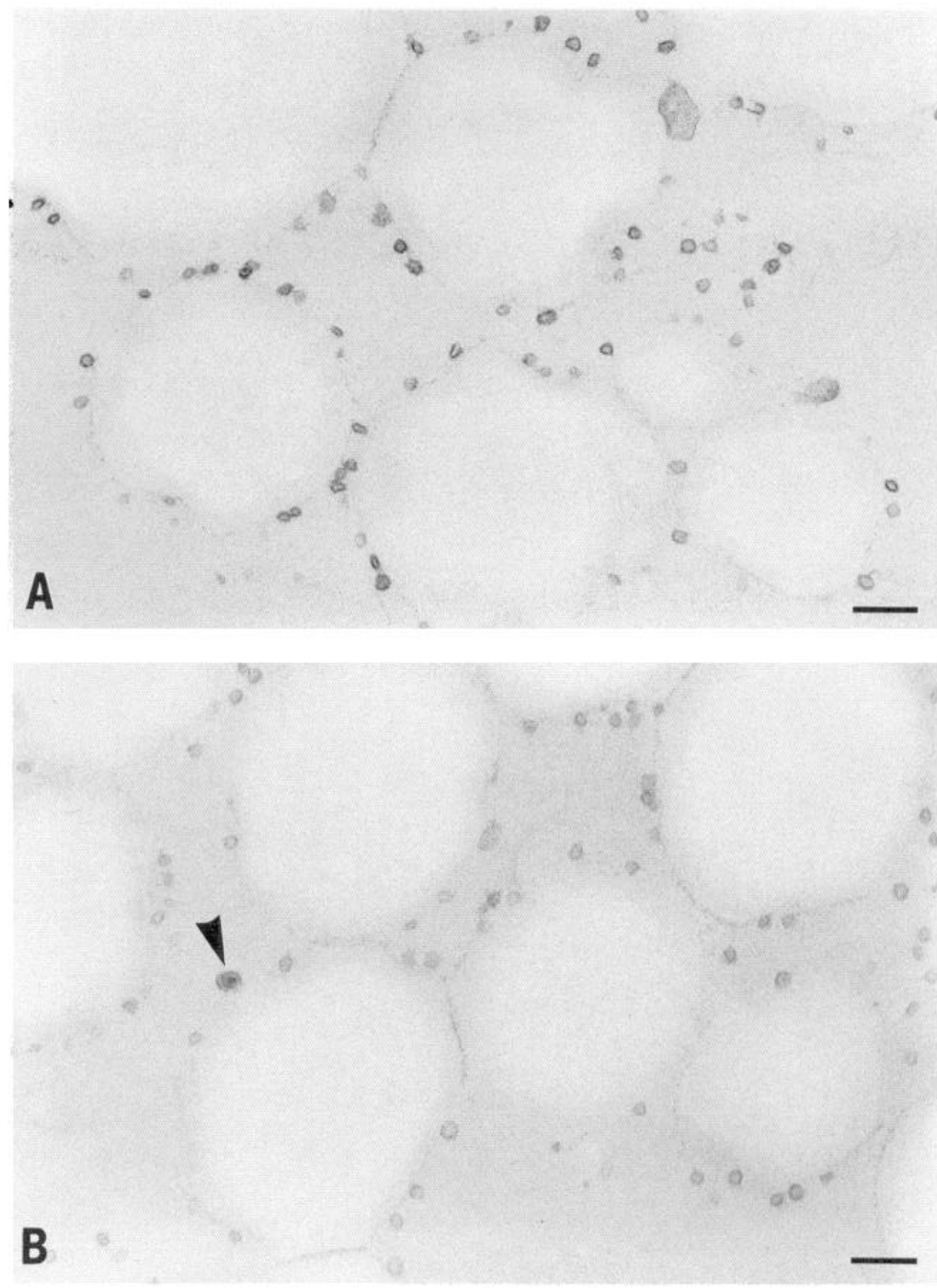

Figure 2. Electron microscopy of organelles immunoisolated from rat hypothalamus using synaptophysin beads $(A)$, synaptotagmin beads $(B)$, and control beads (coupled to bovine $\mathrm{IgG})(C)$. The beads were obtained after incubation with crude homogenate without further purification. In fields $A$ and $B$, the surface of the beads is mainly covered with small vesicular profiles corresponding to SVs. In $A$, occasional larger, irregularly shaped profiles are seen that probably correspond to other compartments of the SV pathway. Synapotagmin beads $(B)$ contain, in addition, larger profiles with an electrondense core typical for LDCVs (arrowhead). Scale bars, $200 \mathrm{~nm}$.

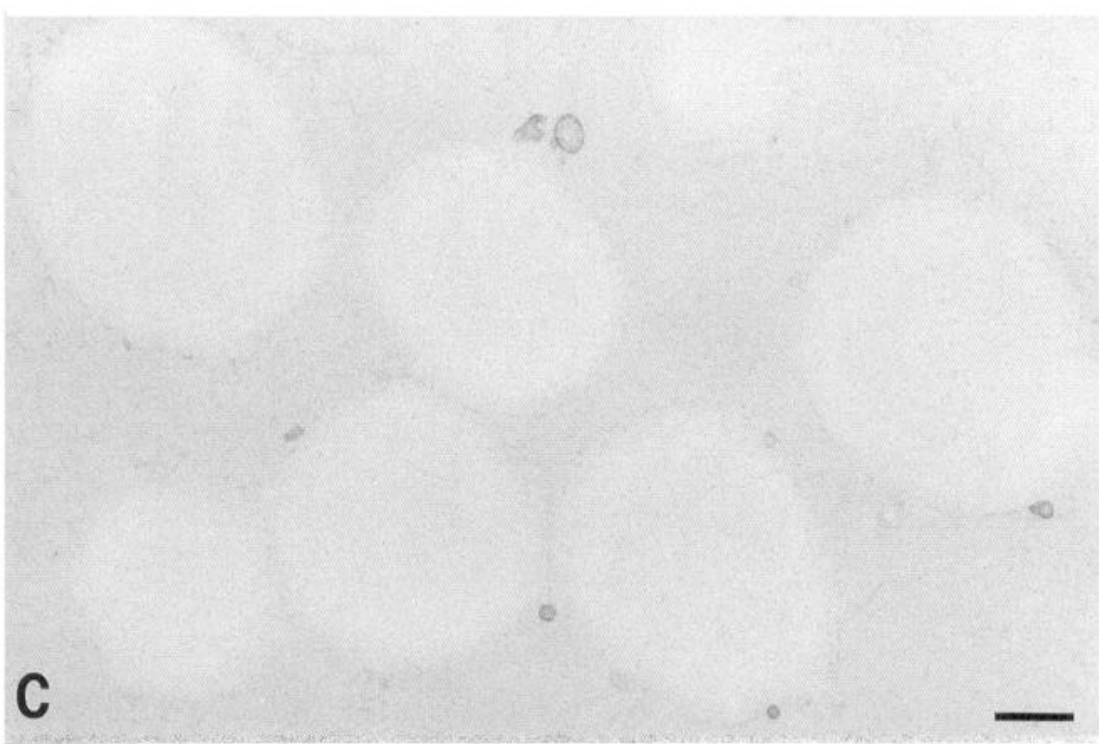




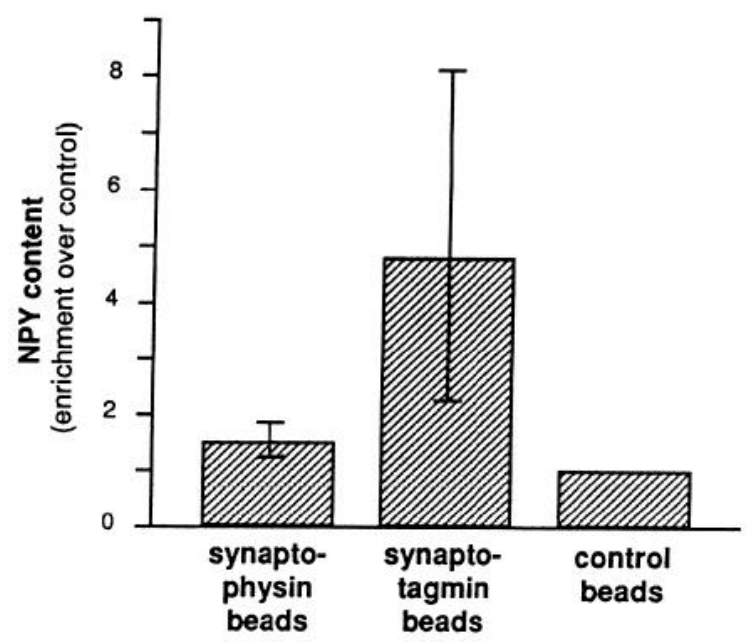

Figure 3. NPY was present only in organelles isolated with synaptotagmin beads but not with synaptophysin beads. A postnuclear supernatant of the rat hypothalamus was incubated with synaptophysin beads, synaptotagmin beads, or control beads (inactivated with glycine) as described in Materials and Methods $(0.75 \mathrm{mg}$ protein $/ \mu 1$ beads). The NPY content in each bead fraction was determined by radioimmunoassay. Shown are data from four independent experiments.

granules (Scherman et al., 1982; Russell et al., 1984). In contrast, synaptophysin, SV2, and p29 were restricted to the microvesicle-containing fractions and were absent from the peak of neurosecretory granules, verifying that these microvesicles were identical with SVs of conventional nerve endings. In summary, these data showed that synaptotagmin, together with cytochrome b561 and the vacuolar proton pump, is also a resident protein of organelles denser than SVs, most likely neurosecretory granules, whereas synaptophysin, SV2, and p29 are selectively localized on microvesicles. To confirm further the absence of synaptophysin from neurosecretory granules, the peak fractions containing neurosecretory granules were pooled and synaptotagmin-containing membranes were immunoisolated using synaptotagmin beads. For comparison, microvesicle-containing fractions were pooled and immunoadsorbed with synaptophysin beads. As shown in Figure 6, membranes isolated from the neurosecretory granule fraction were enriched in synaptotagmin but lacked even trace amounts of synaptophysin. In contrast, membranes isolated from the microvesicle peak contained both synaptotagmin and synaptophysin. Interestingly, only minor amounts of cytochrome b561 were found in organelle fractions isolated with synaptophysin beads, indicating that this protein may be absent from the microvesicles. The presence of this protein at the position of the microvesicles in the sucrose gradient is probably due to the presence of membranes derived from lysed neurosecretory granules.

\section{Discussion}

In the present study, we have used an immunoisolation procedure to prepare membrane vesicles containing synaptophysin and synaptotagmin, respectively, in a single step from crude homogenate fractions (Burger et al., 1989). The results have confirmed previous observations that this procedure yields fractions of exceptional purity with only negligible nonspecific contamination. The data have demonstrated that synaptotagmin I, the predominant isoform of synaptotagmin, is present in at least a subpopulation of LDCVs from brain. Since one or more iso-

\section{immunoisolation with}
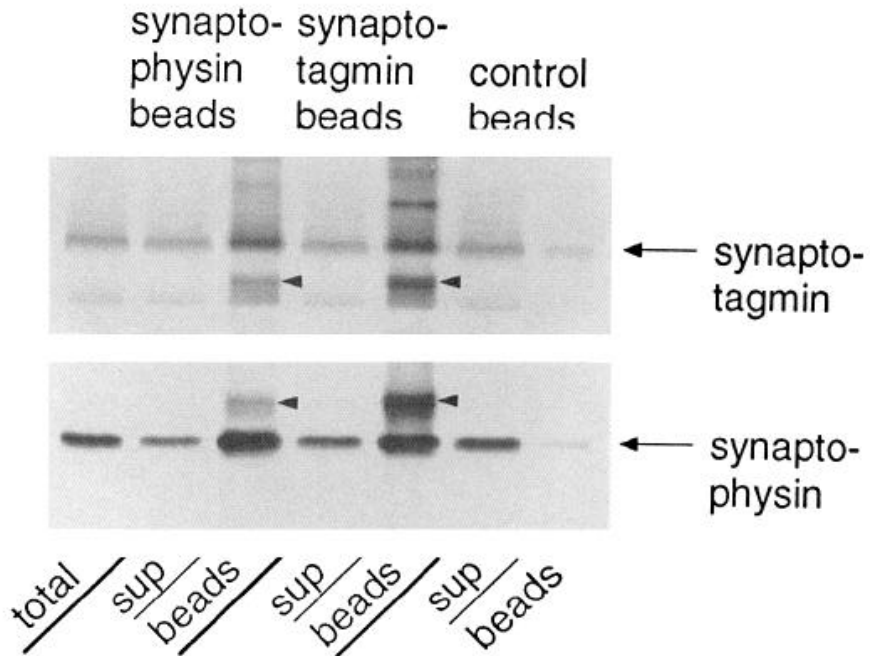

Figure 4. To ensure that both synaptotagmin and synaptophysin beads bound vesicles with equal efficiency, $1 \mu \mathrm{l}$ of each bead fraction was analyzed by immunoblotting for the presence of synaptotagmin and synaptophysin using the alkaline phosphatase method. For comparison, the postnuclear supernatant as well as the supernatants remaining after the respective bead incubations were separated in parallel. Note that bead incubation did not deplete the supernatants of synaptotagmin or synaptophysin since an excess of postnuclear supernatant was used. Arrowheads point to the position of IgG heavy chains of the monoclonal antibodies $\mathrm{C} 7.2$ and $\mathrm{Cl} 41.1$.

forms of synaptotagmin appear to be expressed in all neurons (Matthew et al., 1981; Geppert et al., 1991), it is likely that most LDCV membranes contain a member of the synaptotagmin protein family. However, a generalization of these observations is dependent on the availability of antibodies specific for synaptotagmin II. In contrast, our findings argue against the presence of synaptophysin in mature LDCVs as reported by several authors (Lowe et al., 1988; Obendorf et al., 1988, 1989; Fournier et al., 1989; Schwarzenbrunner et al., 1990), which confirms previous findings (Navone et al., 1986, 1989).

Previous studies addressed the question of an overlap in membrane composition between SVs and peptide-containing secretory vesicles (LDCVs and endocrine granules), with partially mixed results. In some studies it has been suggested that SVs share most of their components with LDCVs and secretory granules, whereas in other studies from our as well as other laboratories, important differences between the two organelles have been reported. In early reports, synaptotagmin (then named p65) was identified on SVs as well as on LDCVs and secretory granules both by immunoperoxidase electron microscopy and immunoisolation (Matthew et al., 1981; Floor and Leeman, 1985). More recently, studies using subcellular fractionation techniques have demonstrated differences between the localization of synaptophysin and synaptotagmin (Volknandt et al., 1988; Fournier et al., 1989; Winkler and Fischer-Colbrie, 1990; Schmidle et al., 1991). Most of these studies were performed in cells containing biogenic amines such as adrenal medulla and PC12 cells. In the adrenal medulla, a relative enrichment of synaptotagmin over synaptophysin was found in fractions enriched in chromaffin granules, suggesting that synaptotagmin is present in the chromaffin granule membrane. In these studies varying amounts of synaptophysin were also found in the granule frac- 

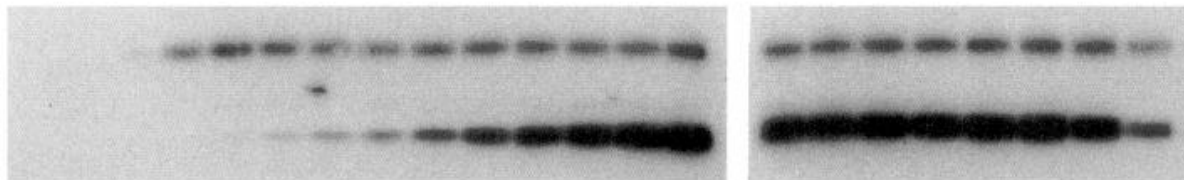

synaptotagmin

synaptophysin
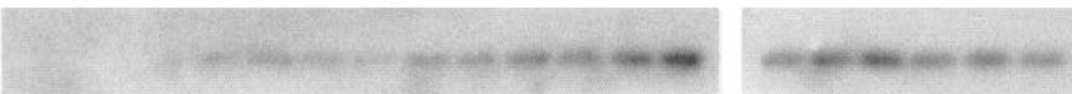

pp $116 \mathrm{kDa}$
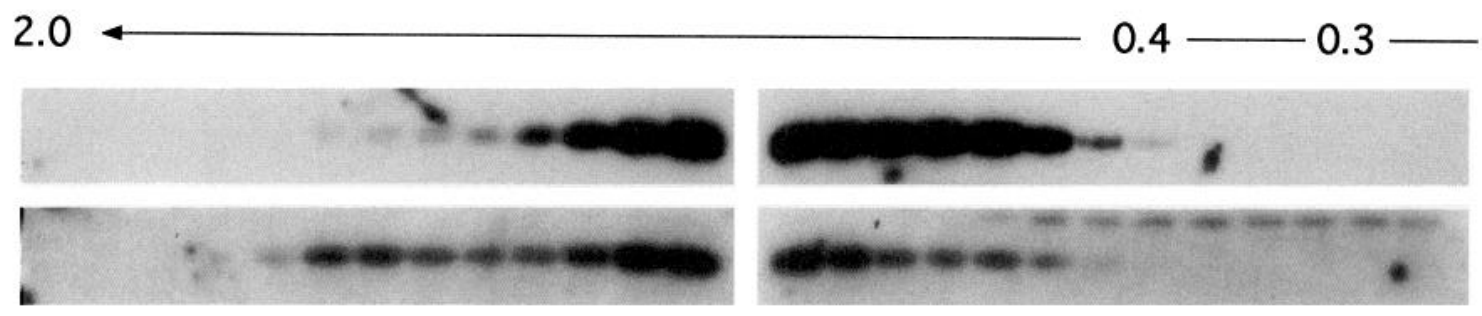

sucrose (M)

synaptophysin
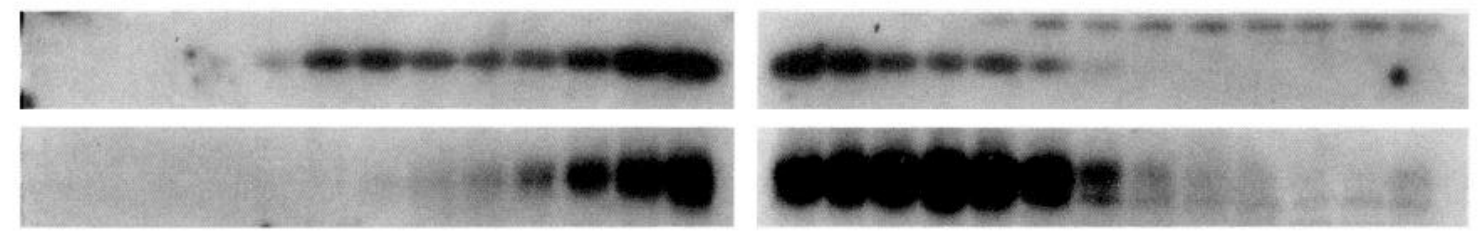

cyt b561

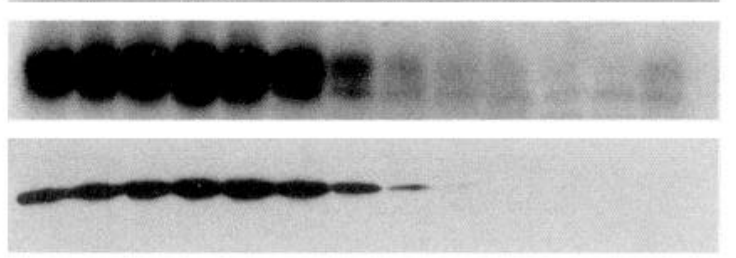

SV2
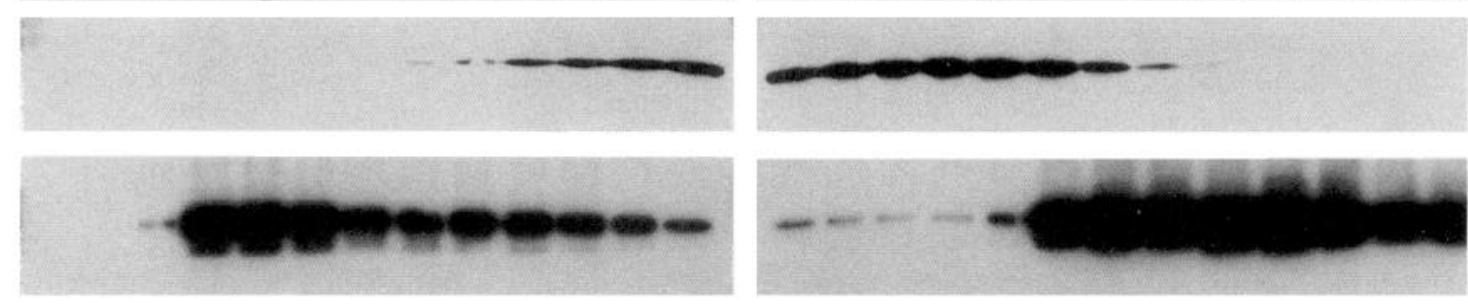

p29
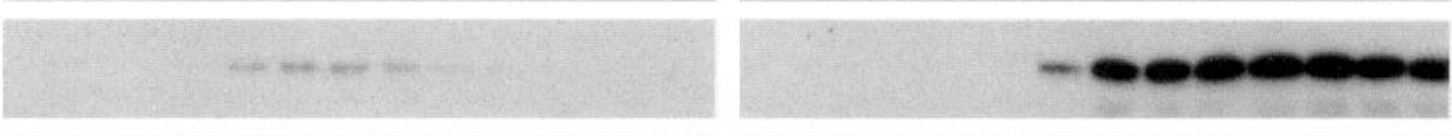

secretogranin II
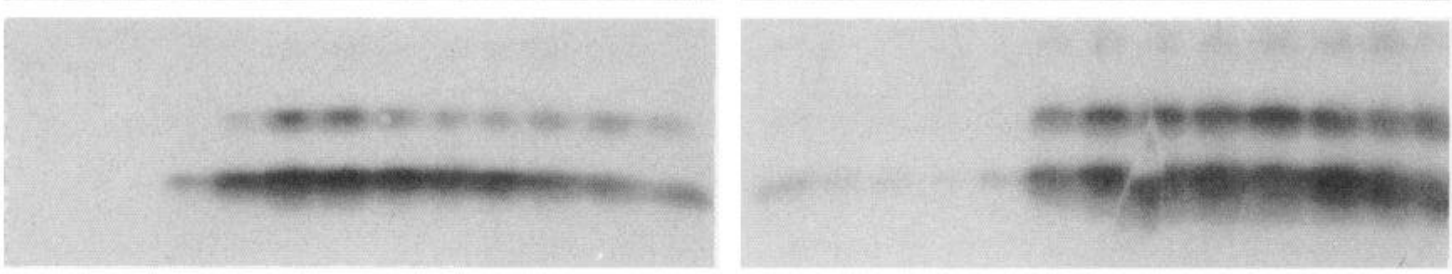

chromogranin A

Figure 5. Distribution of a panel of membrane and content proteins following sucrose density gradient fractionation of postnuclear supernatants from the bovine posterior pituitary. Fractions of $1.4 \mathrm{ml}$ were collected from the bottom of the gradient and equal volumes of each fraction were analyzed by SDS-PAGE and immunoblotting. The proteins were visualized by incubation with ${ }^{125}$ I-protein $\mathrm{A}$ and autoradiography with the exception of p29 that was detected by incubation with peroxidase-coupled secondary antibody and enhanced chemiluminescence. The figure shows the results obtained from two independent gradients (upper and lower panels, respectively). The immunoreactive bands of lower mobility (upper bands) in the cytochrome b561 (cyt b561) panel are due to a nonspecific cross-reaction with an unknown soluble protein. $p p 116 \mathrm{kDa}$ stands for the $116 \mathrm{kDa}$ subunit of the vacuolar proton pump.

tion. We did not detect significant levels of synaptophysin in purified chromaffin granules by either immunogold microscopy or subcellular fractionation (Navone et al., 1986; Fischer von Mollard et al., 1990; Perin et al., 1991a; see also Wiedenmann et al., 1988). Thus, it appears that synaptotagmin is a constituent of at least a subpopulation of LDCVs in the nervous system as well as of secretory granules in chromaffin cells. Our present results agree in this respect with the conclusions of Matthew et al. (1981), Fournier et al. (1989), Trifaro et al. (1989), and Schmidle et al. (1991).

The distribution of cytochrome b561 and the $116 \mathrm{kDa}$ subunit of the proton pump in the posterior pituitary was similar to that of synaptotagmin. Whereas the vacuolar proton pump has been previously demonstrated to be a constituent of both SVs (Hell 


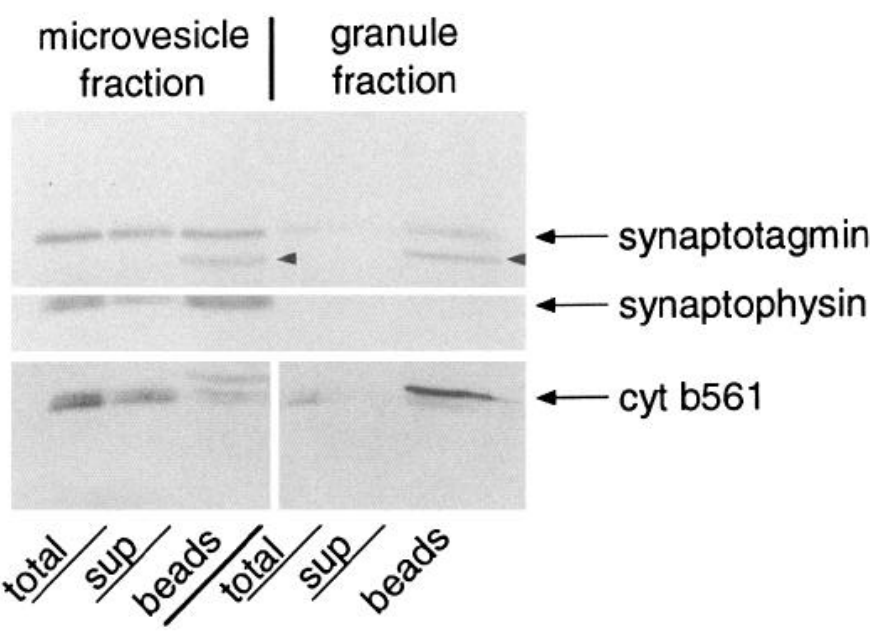

Figure 6. Immunobead isolation of organelles from pooled peak fractions corresponding to the position of neurosecretory granules (granule fraction, 1.3-2.0 $\mathrm{M}$ sucrose) and microvesicles (microvesicle fraction, $0.6-1.0 \mathrm{M}$ sucrose). The fractions were obtained following sucrose density gradient centrifugation of postnuclear supernatants of bovine neurosecretosomes (see Fig. 5). The microvesicle pool was incubated with synaptophysin beads and the granule pool with synaptotagmin beads, respectively; $2.5 \mu$ l of the resulting bead fractions was analyzed by SDSPAGE and immunoblotting for (alkaline phosphatase method for synaptophysin and synaptotagmin, peroxidase-enhanced chemiluminescence method for cytochrome b561). For comparison, equal volumes of the starting material as well as the supernatants remaining after the respective bead incubations were analyzed in parallel. Note the absence of synaptophysin in the granule-derived bead fraction. Cytochrome b561 enriched with synaptotagmin beads but not with synaptophysin beads. Arrowheads indicate position of the IgG heavy chain.

et al., 1988; Cidon and Sihra, 1989; Yamagata and Parsons, 1989; Floor et al., 1990) and secretory granules (for review, see Mellman et al., 1986, and Stone et al., 1989), it appears that cytochrome b561, a redox shuttle required for peptide processing enzymes, is absent from SVs. The presence of cytochrome b561 in the SV fractions may be due to membrane fragments of lysed neurosecretory granules that would colocalize in these fractions.

The findings reported here confirm earlier observations that synaptophysin is selectively localized on SVs and SLMVs (Wiedenmann and Franke, 1985; Navone et al., 1986, 1989; Wiedenmann et al., 1988; Cutler and Cramer, 1990; Fischer von Mollard et al., 1990; Schweitzer and Paddock, 1990; Reetz et al., 1991). In addition, the proteins p29 and SV2 appear to share this distribution (although their presence in LDCV membranes at low concentrations cannot be ruled out). However, the differences in membrane composition observed here further support the view that SVs and LDCVs are organelles of two different secretory pathways whose components are independently sorted. LDCVs are formed by protein condensation in dilated sacs of the TGN (Broadwell and Oliver, 1981; Kagotani et al., 1991). SV proteins follow a different route from LDCVs after exiting the TGN. In PC12 cells, synaptophysin leaves the TGN together with vesicles of the constitutive secretory pathway and is sorted away from this pathway in endosomes into SVs after one or several rounds of constitutive membrane recycling (Cutler and Cramer, 1990; Cameron et al., 1991; Régnier-Vigoroux et al., 1991). Furthermore, recent experiments have suggested that the biogenesis of SVs and LDCVs is differentially regulated in cultures of hypothalamic neurons (Tixier-Vidal et al., 1992).
Of the SV proteins thought to be involved in vesicular membrane traffic (Südhof and Jahn, 1991), synaptotagmin is so far the only protein that is present on both types of secretory organelles undergoing $\mathrm{Ca}^{2+}$-dependent exocytosis. This emphasizes the central importance of this protein previously suggested by its unique properties as a $\mathrm{Ca}^{2+}$-binding protein and a specific binding site for the plasma membrane proteins neurexin and syntaxin [Bennett et al., 1992; see also Hirai et al., 1992 (epimorphin), and Inoue et al., 1992 (HPC-1)]. However, the lack of synaptophysin and the other SV proteins on LDCV membranes does not necessarily imply that these proteins perform functions required exclusively for the SV pathway and not required for the LDCV pathway. Recent findings have indicated that most, if not all, SV proteins belong to protein families that are larger than originally anticipated. In particular, the discovery of non-neuronal isoforms of synaptophysin (Zhong et al., 1992) and synaptobrevin (McMahon et al., 1993; see also Cain et al., 1992) suggests that these protein families have functions fundamental for basic steps of membrane traffic such as membrane fusion or budding. It is possible that LDCVs contain hitherto unknown isoforms of SV-specific proteins that are functionally equivalent to their SV counterparts but are differentially sorted during vesicle biogenesis.

\section{References}

Agoston DV, Whittaker VP (1989) Characterization, by size, density, osmotic fragility, and immunoaffinity, of acetylcholine- and vasoactive intestinal polypeptide-containing storage particles from myenteric neurones of the guinea-pig. J Neurochem 52:1474-1480.

Baumert M, Takei K, Hartinger J, Burger PM, Fischer von Mollard G, Maycox PR, De Camilli P, Jahn R (1990) P29: a novel tyrosinephosphorylated membrane protein present in small clear vesicles of neurons and endocrine cells. J Cell Biol 110:1285-1294.

Bennett MK, Calakos N, Scheller RH (1992) Syntaxin: a synaptic protein implicated in docking of synaptic vesicles at presynaptic active zones. Science 257:255-259.

Bradford MM (1976) A rapid and sensitive method for the quantitation of microgram quantities of protein utilizing the principle of protein-dye-binding. Anal Biochem 72:248-254.

Broadwell RD, Oliver C (1981) Golgi apparatus, GERL, and secretory granule formation within neurons of the hypothalamo-neurohypophysial system of control and hyperosmotically stressed mice. J Cell Biol 90:474-484.

Brose N, Petrenko AG, Südhof TC, Jahn R (1992) Synaptotagmin: a calcium sensor on the synaptic vesicle surface. Science 256:10211025.

Buckley K, Kelly RB (1985) Identification of a transmembrane glycoprotein specific for secretory vesicles of neural and endocrine cells. J Cell Biol 100:1284-1294.

Burger PM, Mehl E, Cameron PL, Maycox PR, Baumert M, Lottspeich F, De Camilli P, Jahn R (1989) Synaptic vesicles immunoisolated from rat cerebral cortex contain high levels of glutamate. Neuron $3: 715-720$.

Cain CC, Trimble WS, Lienhard GE (1992) Members of the VAMP family of synaptic vesicle proteins are components of glucose transporter-containing vesicles from adipocytes. J Biol Chem 267:1168111684.

Cameron PL, Südhof TC, Jahn R, De Camilli P (1991) Colocalization of synaptophysin with transferrin receptors: implications for synaptic vesicle biogenesis. J Cell Biol 115:151-164.

Ceccarelli B, Hurlbut WP, Mauro A (1973) Turnover of transmitter and synaptic vesicles at the frog neuromuscular junction. J Cell Biol 57:499-524.

Cidon S, Sihra TS (1989) Characterization of a $\mathrm{H}^{+}$-ATPase in rat brain synaptic vesicles. J Biol Chem 264:8281-8288.

Cutler DF, Cramer LP (1990) Sorting during transport to the surface of PC12 cells: divergence of synaptic vesicle and secretory granule proteins. J Cell Biol 110:721-730.

De Camilli P, Jahn R (1990) Pathways to regulated exocytosis in neurons. Annu Rev Physiol 52:625-645. 
Duong LT, Fleming PJ, Russell JT (1984) An identical cytochrome b 561 is present in bovine adrenal chromaffin vesicles and posterior pituitary neurosecretory vesicles. J Biol Chem 259:4885-4889.

Fischer von Mollard G, Mignery GA, Baumert M, Perin MS, Hanson TJ, Burger PM, Jahn R, Südhof TC (1990) rab3 is a small GTPbinding protein exclusively localized to synaptic vesicles. Proc Natl Acad Sci USA 87:1988-1992.

Floor E, Leeman SE (1985) Evidence that large synaptic vesicles containing substance $P$ and small synaptic vesicles have a surface antigen in common in rat. Neurosci Lett 60:231-237.

Floor E, Leventhal PS, Schaeffer SF (1990) Partial purification and characterization of the vacuolar H-ATPase of mammalian synaptic vesicles. J Neurochem 55:1663-1670.

Fournier S, Trifaró J-M (1988) A similar calmodulin-binding protein expressed in chromaffin, synaptic, and neurohypophyseal secretory vesicles. J Neurochem 50:27-37.

Fournier S, Novas ML, Trifaró J-M (1989) Subcellular distribution of 65.000 calmodulin-binding protein (p65) and synaptophysin (p38) in adrenal medulla. J Neurochem 53:1043-1049.

Fried G, Lagercrantz H, Hökfelt T (1978) Improved isolation of small noradrenergic vesicles from rat seminal ducts following castration. A density gradient centrifugation and morphological study. Neuroscience 3:1271-1291.

Geppert M, Archer BT, Südhof TC (1991) Synaptotagmin II. A novel differentially distributed form of synaptotagmin. J Biol Chem 266: 13548-13552.

Harlow E, Lane D (1988) Antibodies. A laboratory manual. Cold Spring Harbor, NY: Cold Spring Harbor Laboratory.

Hell JW, Maycox PR, Stadler H, Jahn R (1988) Uptake of GABA by rat brain synaptic vesicles isolated by a new procedure. EMBO J 7:3023-3029.

Heuser JE, Reese TS (1973) Evidence for recycling of synaptic vesicle membrane during transmitter release at the frog neuromuscular junction. J Cell Biol 57:315-344

Hirai Y, Takebe K, Takashina M, Kobayashi S, Takeichi M (1992) Epimorphin: a mesenchymal protein essential for epithelial morphogenesis. Cell 69:471-481.

Hökfelt T (1991) Neuropeptides in perspective: the last ten years. Neuron 7:867-879.

Huttner WB, Schiebler W, Greengard P, De Camilli P (1983) Synapsin I (protein I), a nerve terminal-specific phosphoprotein. III. Its association with synaptic vesicles studied in a highly purified synaptic vesicle preparation. J Cell Biol 96:1374-1388.

Inoue A, Obata K, Akagawa K (1992) Cloning and sequence analysis of cDNA for a neuronal cell membrane antigen, HPC-1. J Biol Chem 267:10613-10619.

Jahn R, Schiebler W, Ouimet CH, Greengard P (1985) A 38,000dalton membrane protein (p38) present in synaptic vesicles. Proc Natl Acad Sci USA 82:4137-4141.

Jung LJ, Scheller RH (1991) Peptide processing and targeting in the neuronal secretory pathway. Science 251:1330-1335.

Kagotani Y, Picart R, Barret A, Wiedenmann B, Huttner WB, TixierVidal A (1991) Subcellular localization of secretogranin II and synaptophysin by immunoelectron microscopy in differentiated hypothalamic neurons in culture. J Histochem Cytochem 39:1507-1518.

Klein RL, Thureson-Klein AK (1990) Neuropeptide co-storage and exocytosis by neuronal large dense-cored vesicles: how good is the evidence? Curr Aspects Neurosci 2:219-258.

Laemmli UK (1970) Cleavage of structural proteins during the assembly of the head of bacteriophage T4. Nature 227:680-685.

Lowe AW, Madeddu L, Kelly RB (1988) Endocrine secretory granules and neuronal synaptic vesicles have three integral membrane proteins in common. J Cell Biol 106:51-59.

Marek KL, Mains RE (1989) Biosynthesis, development and regulation of ncuropeptide $\mathrm{Y}$ in superior cervical ganglion culture. J Neurochem 52:1807-1816.

Matteoli M, Haimann C, Torri-Tarelli F, Polak JM, Ceccarelli B, De Camilli P (1988) Differential effect of alpha-latrotoxin on exocytosis from small synaptic vesicles and from large dense-core vesicles containing calcitonin gene-related peptide at the frog neuromuscular junction. Proc Natl Acad Sci USA 85:7366-7370.

Matthew WD, Tsavaler L, Reichardt LF (1981) Identification of a synaptic vesicle-specific membrane protein with a wide distribution in neuronal and neurosecretory tissue. J Cell Biol 91:257-269.

McMahon H, Ushkaryov YA, Edelman L, Niemann H, Fahn R, Südhof
TC (1993) Cellubrevin: a ubiquitous tetanus-toxin substrate homologous to a putative synaptic vesicle fusion protein. Nature, in press.

Mellman I, Fuchs R, Helenius A (1986) Acidification of the endocytic and exocytic pathways. Annu Rev Biochem 55:663-700.

Navone F, Greengard P, De Camilli P (1984) Synapsin I in nerve terminals: selective association with small synaptic vesicles. Science 226:1209-1211.

Navone F, Jahn R, Di Gioia G, Stukenbrok H, Greengard P, De Camilli $P$ (1986) Protein p38: an integral membrane protein specific for small vesicles of neurons and neuroendocrine cells. J Cell Biol 103: 2511-2527.

Navone F, Di Gioia G, Jahn R, Browning M, Greengard P, De Camilli $P$ (1989) Microvesicles of the neurohypophysis are biochemically related to small synaptic vesicles of presynaptic nerve terminals. J Cell Biol 109:3425-3433.

Obendorf D, Schwarzenbrunner U, Fischer-Colbrie R, Laslop A, Winkler $H$ (1988) In adrenal medulla synaptophysin (protein $p 38$ ) is present in chromaffin granules and in a special vesicle population. J Neurochem 51:1573-1580.

Obendorf D, Schwarzenbrunner U, Fischer-Colbrie R, Scherman D, Hook V, Winkler H (1989) Do large and small dense core vesicles of sympathetic nerve contain the same antigens? J Neurochem 52[Suppl 84]:S84.

Orci L, Ravazzola M, Amherdt M, Perrelet A, Powell S, Quinn DL, Moore H-PH (1987) The trans-most cisternac of the Golgi complex: a compartment for sorting of secretory and plasma membrane proteins. Cell 51:1039-1051.

Perin M, Fried VA, Slaughter CA, Südhof TC (1988) The structure of cytochrome b561, a secretory vesicle specific electron transport protein. EMBO J 7:2697-2703.

Perin MS, Fried VA, Mignery GA, Jahn R, Südhof TC (1990) Phospholipid binding by a synaptic vesicle protein homologeous to the regulatory domain of protein kinase C. Nature 345:260-263.

Perin MS, Brose N, Jahn R, Südhof TC (1991a) Domain structure of synaptotagmin (p65). J Biol Chem 266:623-629.

Perin MS, Fried VA, Stone DK, Xie X-S, Südhof TC (1991b) Structure of the 116-kDa polypeptide of the clathrin-coated vesicle/synaptic vesicle proton pump. J Biol Chem 266:3877-3881.

Petrenko AG, Perin MS, Davletov BA, Ushkaryov YA, Geppert M, Südhof TC (1991) Binding of synaptotagmin to the $\alpha$-latrotoxin receptor implicates both in synaptic exocytosis. Nature 353:65-68.

Reetz A, Solimena M, Matteoli M, Folli F, Takei K, De Camilli P (1991) GABA and pancreatic $\beta$-cells: colocalization of glutamic acid decarboxylase (GAD) and GABA with synaptic-like microvesicles suggests their role in GABA storage and secretion. EMBO J 10:12751284.

Régnier-Vigoroux A, Tooze SA, Huttner WB (1991) Newly synthesized synaptophysin is transported to synaptic-like microvesicles via constitutive secretory vesicles and the plasma membrane. EMBO J 10:3589-3601.

Russell JT (1980) The isolation of purified neurosecretory vesicles from bovine neurohypophysis using isoosmolar density gradients. Anal Biochem 113:229-238.

Russell JT (1984) $\Delta \mathrm{pH}, \mathrm{H}^{+}$diffusion potentials, and $\mathrm{Mg}^{2+}$ ATPase in neurosecretory vesicles isolated from bovine neurohypophyses. J Biol Chem 259:9496-9507.

Scherman D, Nordmann J, Henry J-P (1982) Existence of an adenosine $5^{\prime}$-triphosphate dependent proton translocase in bovine neurosecretory granules membrane. Biochemistry 21:687-694.

Schmidle T, Weiler R, Desnos C, Scherman D, Fischer-Colbrie R, Floor E, Winkler H (1991) Synaptin/synaptophysin, p65 and SV2: their presence in adrenal chromaffin granules and sympathetic large dense core vesicles. Biochim Biophys Acta 1060:251-256.

Schwarzenbrunner U, Schmidlc T, Obcndorf D, Scherman D, Hook V, Fischer-Colbrie R, Winkler H (1990) Sympathetic axons and nerve terminals: the protein composition of small and large dense-core and of a third type of vesicles. Neuroscience 37:819-827.

Schweitzer ES, Paddock S (1990) Localization of human growth hormone to a sub-set of cytoplasmic vesicles in transfected PC1 2 cells. J Cell Sci 96:375-381.

Stone DK, Crider BP, Südhof TC, Xie X-S (1989) Vacuolar proton pumps. J Bioenerg Biomembr 21:605-620.

Südhof TC, Jahn R (1991) Proteins of synaptic vesicles involved in exocytosis and membrane recycling. Neuron 6:665-677. 
Thureson-KIcin AK, Klcin RL (1990) Exocytosis from ncuronal large dense-cored vesicles. Int Rev Cytol 121:67-126.

Tixier-Vidal A, Barret A, Faivre-Bauman A, Huttner W, Wiedenmann B (1992) Differential expression and subcellular localization of secretogranin II and synaptophysin during early development of mouse hypothalamic neurons in culture. Neuroscience 47:967-978.

Tooze J, Tooze SA, Fuller SD (1987) Sorting of progeny coronavirus from condensed secretory proteins at the exit from the trans-Golgi network of AtT20 cells. J Cell Biol 105:1215-1226.

Tooze SA, Huttner WB (1990) Cell-free protein sorting to the regulated and constitutive secretory pathways. Cell 60:837-847.

Towbin H, Staehelin H, Gordon J (1979) Electrophoretic transfer of proteins from polyacrylamide gels to nitrocellulose sheets: procedure and some applications. Proc Natl Acad Sci USA 76:4350-4354.

Trifaró J-M, Fournier S, Novas ML (1989) The p65 protcin is a calmodulin-binding protein present in several types of secretory vesicles. Neuroscience 29:1-8.

Trimble WS, Llineal M, Scheller RH (1991) Cellular and molecular biology of the presynaptic nerve terminal. Annu Rev Neurosci 14: 93-122.

Ushkaryov YA, Petrenko AG, Geppert M, Südhof TC (1992) Neurexins: synaptic cell surface proteins related to the alpha-latrotoxin receptor and laminin. Science 257:50-56.

Verhage M, Ghijsen WEJM, Nicholls DG, Wiegant VM (1991a) Characterization of the release of cholecystokinin- 8 from isolated nerve tcrminals and comparison with exocytosis of classical transmitters. $\mathrm{J}$ Neurochem 56:1394-1400.

Verhage M, McMahon HT, Ghijsen WEJM, Boomsma F, Scholten G, Wiegant VM, Nicholls DB (199lb) Differential release of amino acids, neuropeptides, and catecholamines from isolated nerve terminals. Neuron 6:517-524.

Volknandt W, Henkel A, Zimmermann H (1988) Heterogeneous distribution of synaptophysin and protein 65 in synaptic vesicles isolated from rat cerebral cortex. Neurochem Int 12:337-345.

Wiedenmann B, Franke W (1985) Identification and localization of synaptophysin, an integral membrane glycoprotein of $M, 38,000$ characteristic of presynaptic vesicles. Cell 41:1071-1028.

Wiedenmann B, Rehm H, Knierim M, Becker C-M (1988) Fractionation of synaptophysin-containing vesicles from rat brain and cultured $\mathrm{\Gamma C1} 2$ pheochromocytoma cells. FEDS Lett 240:71-77.

Winkler H, Fischer-Colbrie R (1990) Common membrane protein of chromaffin granules, endocrine and synaptic vesicles: properties, tissue distribution, membrane topography and regulation of synthesis. Neurochem Int 17:245-262.

Yamagata SK, Parsons SM (1989) Cholinergic synaptic vesicles contain a V-type and a P-type ATPase. J Neurochem 53:1354-1362.

Zhong C, Hayzer DJ, Runge MS (1992) Molecular cloning of a cDNA encoding a novel protein related to the neuronal vesicle protein synaptophysin. Biochim Biophys Acta 1129:235-238. 